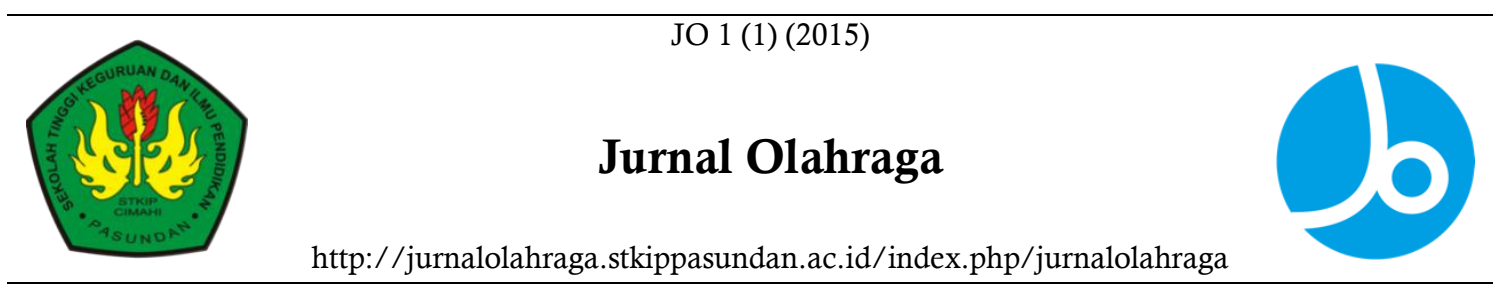

\title{
Studi Korelasi Kelincahan, Kecepatan dan Motivasi Latihan terhadap Kemampuan Menggiring Bola Futsal pada Unit Kegiatan Mahasiswa Futsal Stkip Pasundan Cimahi
}

Gugun Gunawan

STKIP Pasundan, Indonesia

\begin{tabular}{l}
\hline Info Artikel \\
\hline Sejarah Artikel: \\
Diterima Januari 2015 \\
Disetujui Maret 2015 \\
Dipublikasikan April 2015 \\
\hline Keywords: \\
kelincahan, kecepatan, motivasi \\
berlatih, kemampuan \\
menggiring bola. \\
\hline
\end{tabular}

\section{Abstrak}

Tujuan penelitian ini adalah untuk mengetahui korelasi kelincahan, kecepatan dan motivasi latihan terhadap kemampuan menggiring bola futsal pada unit kegiatan mahasiswa futsal STKIP Pasundan Cimahi. Penelitian dilakukan kepada 28 orang sampel penelitian dengan menggunakan metode korelasi. Untuk mengumpulkan data penulis menggunakan tes dan angket. Tes dilakukan untuk mengukur kelincahan adalah circuit training, tes untuk mengkur kecepatan adalah lari 20 meter dan tes untuk mengukur kemampuan menggiring bola adalah tes boomerang. Hasil penelitian ini adalah: Pertama, ada korelasi positif dan signifikan dari kelincahan terhadap kemampuan menggiring bola dengan koefisien korelasi 0,67 dan besar indeks determinasi sebesar 44,89\%. Kedua ada korelasi positif dan singifikan dari kelincahan terhadap kemampuan menggiring bola dengan koefisien korelasi 0,484 dan besar indeks determinasi sebesar $23,43 \%$. Ketiga ada korelasi positif dan singifikan dari kelincahan terhadap kemampuan menggiring bola dengan koefisien korelasi 0,398 dan besar indeks determinasi sebesar $15,84 \%$. Keempat ada korelasi positif dan singifikan secara bersama-sama dari variable kelicahan, kecepatan dan kemampuan menggiring bola dengan koefisien korelasi 0.517 dan besar indeks determinasi sebesar 28.05\%. Dari hasil analisis data dapat disimpulkan bahwa untuk meningkatkan kemampuan menggiring bola bisa dilakukan secara fisik dengan melatih kelincahan dan kecepatan siswa sedangkan secara psikis dengan meningkatkan motivasi berlatih. Masih terdapat variable lain yang turut mempengaruhi kemampuan menggiring bola selain dari variable tersebut di atas tetapi luput dari proses penelitian. Oleh karena itu perlu dilakukan lebih lanjut dengan memperluas cakupan bahasan penelitian.

\author{
Abstract \\ The purpose of this study is to know the correlation of agility, speed \\ and motivation of training on the ability to dribble futsal in the \\ futsal student unit STKIP Pasundan Cimahi. The study was \\ conducted on 28 research samples using the correlation method. To
}


collect data the author uses tests and questionnaires. Tests carried out to measure agility are circuit training, tests to measure speed are 20 meters running and tests to measure dribbling skills are boomerang tests. The results of this study are: First, there is a positive and significant correlation of agility to the ability of dribbling with a correlation coefficient of 0.67 and a large index of determination of $44.89 \%$. Second, there is a positive and significant correlation of agility to the ability to dribble with a correlation coefficient of 0.484 and a large index of determination of $23.43 \%$. Third, there is a positive and significant correlation of agility to the ability to dribble with a correlation coefficient of 0.398 and a large index of determination of $15.84 \%$. Fourth, there is a positive and significant correlation together from the variable of agility, speed and ability to dribble with a correlation coefficient of 0.517 and a large index of determination of $28.05 \%$. From the results of data analisys it can be concluded that to improve the ability of dribbling can be done physically by practicing student agility and speed while psychologically by increasing motivation to practice. There are still other variables that also influence the ability to dribble apart from the variables mentioned above but escape the research process. Therfore it needs to be done further by expanding the scope of the research discussion.

(C) 2015 Gugun Gunawan

Under the license CC BY-SA 4.0

Alamat korespondensi:

E-mail: -

ISSN 2442-9661 (cetak)

\section{PENDAHULUAN}

Bila kita mengamati kemampuan menggiring bola maka kita bisa menyimpulkan terdapat faktor fisik berupa kelincahan dan kecepatan serta faktor psikis seperti motivasi. Untuk mencapai prestasi yang tinggi diperlukan pembinaan, pelatihan dan pengajaran.Beberapa langkah dalam pembinaan, pelatihan dan pengajaran yang sangat penting adalah proses pembinaan, pelatihan dan pengajaran tentang teknik bermain, taktik dalam pertandingan, latihan kondisi fisik dan mental yang baik dalam futsal. Hal yang sangat penting untuk dilakukan adalah penguasaan teknik dasar.
Oleh karena itu, menurut Lakhsana (2006:8) diperlukan kemampuan menguasai teknik dasar bermain futsal seperti, 'teknik dasar mengumpan (Passing), teknik dasar menahan bola (control), teknik mengumpan lambung (chipping), teknik dasar menggiring bola (dribbling), teknik dasar menembak (shooting)'.

Salah satu teknik dasar yang memerlukan pembinaan, pelatihan dan pengajaran yang amat penting adalah teknik menggiring bola. menggiring bola adalah salah satu teknik yang banyak menarik fokus perhatian serta dijadikan langkah awal untuk menciptakan kemenangan dalam setiap 
pertandingan di samping teknik-teknik yang lainnya. Menggiring bola adalah memainkan bola sambil berlari yang dapat dilakukan dengan arah lurus maupun berbelok-belok.

Olahraga futsal sebenarnya merupakan olahraga yang sangat kompleks, karena memerlukan teknik bermain dan strategi yang mumpuni. Begitu pula dalam hal kemampuan kondisi fisik. Permainan futsal memiliki perbedaan yang sangat khas dengan cabang olahraga lainnya. Salah satu karakteristik olahraga futsal yaitu membutuhkan daya tahan kekuatan, kecepatan, daya tahan kelincahan, keseimbangan, kelentukan dalam kurun waktu yang cukup lama. Hal-hal tersebut merupakan beberapa faktor yang mempengaruhi performa dalam bermain futsal. Kondisi fisik yang prima sangatlah menunjang penampilan seorang pemain, karena di futsal seorang pemain selalu berubah tempat dan atau terus bergerak. Kelincahan sangat dibutuhkan oleh seorang pemain futsal dalam menghadapi situasi tertentu dan kondisi pertandingan yang menuntut bergerak untuk menguasai bola maupun dalam bertahan untuk menghindari benturan. Kelincahan adalah sebagai kemampuan seseorang untuk dapat bergerak dan berubah arah gerakan ke berbagai arah untuk membuka ruang dan menghindari penjagaan lawan. Disamping membutuhkan kelincahan untuk mencapai keterampilan menggring bola diperlukan pula unsur fisik lain yaitu kelincahan dan kecepatan.
Kelincahan adalah merupakan salah satu komponen fisik yang sangat diperlukan pada semua aktifitas yang membutuhkan kecepatan perubahan posisi tubuh dan bagian-bagiannya. Selain itu pula, kelincahan merupakan syarat penting untuk mempelajari dan memperbaiki keterampilan gerak dan teknik olahraga, terutama gerakan-gerakan yang membutuhkan koordinasi gerak yang banyak dipergunakan dalam olahraga. Menurut Kirkendall, dkk dalam Ismayati (2008:41) berpendapat bahwa, 'Kelincahan adalah kemampuan untuk mengubah arah dan posisi tubuh atau bagian-bagiannya secara cepat dan tepat'.

Kelincahan kemampuan seseorang mengubah posisi di area tertentu. Seseorang yang mampu mengubah satu posisi yang berbeda dalam kecepatan tinggi dengan koordinasi yang baik,berarti kelincahannya cukup baik. Sedangkan menurut Moelek dan Tjokro (1984:08) memaparkan bahwa, 'Kelincahan adalah kemampuan mengubah secara cepat arah tubuh atau bagian tubuh tanpa gangguan pada keseimbangan'. Kelincahan dibedakan menjadi kelincahan umum, yang biasanya nampak pada aktifitas olahraga dan kelincahan khusus yang berkaitan dengan teknik gerakan olahraga tertentu. Dilihat dari segi anatomis kelincahan umum melibatkan gerakan seluruh segmen bagian tubuh dan kelincahan khusus hanya melibatkan segmen tubuh tertentu.

Dalam komponen kelincahan sudah termasuk unsur mengelak dengan cepat, 
mengubah posisi tubuh dengat tepat, bergerak terus dan menghindari lawan dengan cepat. Kelincahan sangat diperlukan dalam melakukan gerak tipu pada saat menggiring bola. Gerak tipu dapat kita kerjakan dengan mengendalikan ketepatan,kecepatan, dan kecermaterhenti dan dilanjutkan dengan bergerak secepat mungkin. Sesorang yang mampu mengubah satu posisi dengan koordinasi yang baik, maka kelincahannya cukup baik. Kemampuan seperti ini membutuhkan komponen koordinasiyang prima. Seorang atlet agar memiliki kelincahan yang baik yakni harus menguasai kemampuan untuk bergerak secepatnya dari satu titik ke titik lainnya. Kemudian tiba-tiba mengubah arah gerakan, menghindar dengan berkelok-kelok atau mengelilingi objek secepatnya.Kelincahan memiliki karakteristik yang unik, kelincahan memainkan peranan yang khusus tehadap mobilitas fisik.

Kecepatan menurut Bompa (2009:3215) adalah, 'Kemampuan seseorang untuk dapat mencapai jarak dalam waktu singkat'. Harsono (1988:216) juga mengatakan kecepatan adalah sebagai berikut:

Kemampuan untuk melakukan gerakangerakan yang sejenis secara berturut-turut dalam waktu yang sesingkat-singkatnya, atau kemampuan untuk menempuh suatu jarak dalam waktu yang sesingkatsingkatnya. Kecepatan pergerakan seseorang dapat dipengaruhi oleh serabut otot yang dimilikinya, yaitu serabut otot putih dan serabut otot merah, atau campuran serabut gerak cepat dan serabut gerak lambat dan serabut tersebut ditentukan oleh keturunan seseorang juga tidak akan berubah tanpa latihan. Kecepatan dalam olahraga secara umum dapat dibagi menjadi tiga tahap yang antara lain adalah akselerasi (percepatan), pencapaian kecepatan maksimal dan pemeliharaan kecepatan maksimal. Percepatan adalah kemampuan untuk meningkatkan kecepatan gerakan dalam waktu yang minimal.

Menurut Bangso \& Mohr (2003:58) menyatakan bahwa: Percepatan dapat menentukan kemampuan kerja sprint jarak pendek 5-10 meter. Dalam permainan futsal pemain melakukan $5 \%$ sprint dari total jarak dalam satu pertandingan dan terdapat 3-4 sprint dengan waktu pemulihan kurang dari 25 detik. Panjang berlari dalam futsal berkisar antara 5-20 meter rata-rata 10 meter untuk berlari pemain.

Futsal merupakan olahraga beregu yang dimainkan dalam intensitas tinggi dengan lapangan yang relatif kecil dan jumlah pemain yang sedikit adalah sebuah kondisi dasar agar setiap pemain dapat melakukan aktifitas dengan cepat. Kecepatan dalam permainan futsal berbeda dengan sprint $100 \mathrm{~m}$ straight line yang ditempuh dalam waktu kurang dari 10 detik, tetapi kecepatan dalam futsal menurut Bangso \& Mohr (2003:49) adalah 'Kecepatan yang selalu berubah-ubah baik dari jarak dan juga intensitas kecepatan berlari'.

Permasalahan yang lain muncul ketika kemampuan teknik dan kondisi fisik sudah dimiliki pemain, tetapi pada saat pertandingan, bermain, berkompetisi berlangsung dalam diri pemain terhambat 
untuk mengeluarkan kemampuan terbaik yang telah dimilikinya. Ada beberapa faktor psikologis yang dapat mempengaruhi penampilan bermain futsal diantaranya faktor motivasi, percaya diri, konsentrasi, kekreatifan dan kewaspadaan.

Di dalam diri pemain futsal harus tumbuh dan tertanam motivasi terutama motivasi latihan. Motivasi adalah energi psikologis yang bersifat abstrak, wujudnya hanya dapat diamati dalam bentuk manifestasi tingkah laku yang ditampilkannya hal ini terlihat pada saat bertanding dikarenakan faktor psikis ikut mempengaruhi pemain. Motivasi latihan adalah sebagai penggerak yang menimbulkan kegiatan berlatih dalam mencapai keterampilan yang optimal. Suatu hal yang tidak dapat dipisahkan antara kemampuan fisik dan psikologi, diharapkan bisa menghasilkan seorang pemain pada setiap penampilannya memilki motivasi atau dorongan yang kuat untuk bermain dengan sebaik-baiknya sehingga dapat bermain baik untuk dapat memenangkan pertandingan yang dilakukannya.

Berdasarkan uraian latarbelakang yang telah di dikemukakan diatas, maka tujuan pelaksanaan penelitian ini adalah: ingin mengetahui korelasi antara kelincahan, kecepatan dan motivasi berlatih terhadap kemampuan menggiring bola.

\section{METODE}

Metode penelitian yang digunakan adalah metode korelasi. Korelasi yang diteliti adalah korelasi multi variabel karena menurut Arikunto (1996:122) bahwa, 'Pada korelasi multi variablel terdapat empat variabel yang berhubungan'. Sampel yang dipilih haruslah representatif dan sesuai dengan rancangan penelitian. Pengambilan sampel dilakukan dengan menggunakan random Sampling yang berjumlah 28 orang. Random sampling atau pengambilan sampel secara acak. Hubungan antar variabel terlihat seperti pada desain penelitian berikut:

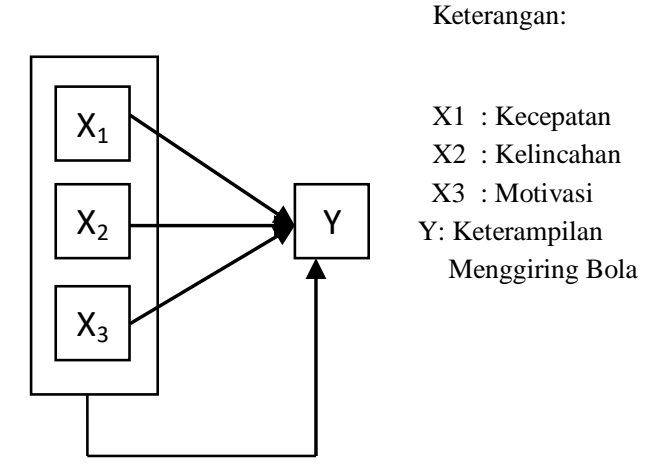

\section{Gambar 1. Desain Penelitian}

Penelitian dilakukan kepada 28 orang subjek penelitian. Karena sumber data berasal dari satu sumber saja maka digunakan teknik pengambilan data dengan menggunakan metode random agar setiap anggota dari populasi memiliki kesempatan yang sama untuk diambil sebagai sampel. Untuk mengumpulkan data digunakan tes dan angket. Tes yang digunakan pada awalnya diajukan dua tes masing-masing untuk variabel kelincahan, kecepatan dan kemampuan menggiring bola. Setelah diuji validitas dan reliabilitasnya maka dipilih satu tes untuk tiap variabel. Berdasarkan hasil uji coba instrument diketahui: 
1. Untuk mengukur kemampuan menggiring bola maka digunakan tes boomerang karena memiliki nilai validitas dan reliabilitas yang lebih tinggi dibandingkan tes segitiga dengan bola.

2.Untuk mengukur kelincahan maka digunakan tes circuit training karena memiliki nilai validitas dan reliabilitas yang lebih tinggi dibandingkan tes segitiga tanpa bola.

3. Untuk tes kecepatan maka digunakan tes lari 20 meter karena memiliki nilai validitas 2 dan reliabilitas yang lebih tinggi dibandingkan tes lari 40 meter

4. Untuk angket yang awalnya terdiri atas 38 butir soal setelah diuji validitas dan reliabilitas nya tedapat tujuh butir yang tidak valid. Butir angket tersebut dibuang sehingga sisa angket yang valid adalah 31. Dan digunakan dalam proses penelitian.

\section{HASIL DAN PEMBAHASAN}

\begin{tabular}{|c|c|c|c|c|c|}
\hline \multirow{2}{*}{ No } & \multirow{2}{*}{ Analisis Data } & \multicolumn{4}{|c|}{ Variabel } \\
\cline { 3 - 6 } & & $\mathrm{X} 1$ & $\mathrm{X} 2$ & $\mathrm{X} 3$ & $\mathrm{Y}$ \\
\hline 1 & Rata-rata & 15.39 & 3.53 & 117.89 & 39.78 \\
\hline 2 & Modus & - & - & 102 & - \\
\hline 3 & Median & 15.44 & 3.54 & 116 & 39.725 \\
\hline 4 & Standar Deviasi & 2.35 & 0.33 & 10.21 & 4.83 \\
\hline 5 & Varians & 5.5225 & 0.1089 & 104.244 & 23.329 \\
\hline 6 & Skor maksimal & 19.88 & 4.05 & 140 & 48.22 \\
\hline 7 & Skor Minimal & 11.15 & 2.82 & 102 & 31.95 \\
\hline 8 & Range & 8.73 & 1.23 & 38 & 16.27 \\
\hline
\end{tabular}

Proses pengolahan data awal meliputi penghitungan rata-rata modus, median, standar deviasi, varians, skor maksimal, skor minimal dan range untuk data nilai mentah dan data nilai standar (Z Score).

Proses pengolahan data meliputi uji korelasi, uji signifikansi dan indeks determinasi. Dari hasil pengolahan data diketahui:

1. Korelasi variabel kelincahan (X1) dan kemampuan menggiring bola (Y) sebesar 0,67.Hasil $t$ hitung uji signifikansi variabel kelincahan (X1) dan kemampuan menggiring bola $(\mathrm{Y})$ sebesar 4.602.Dari hasil uji indeks determinasi diketahui pengaruh kelincahan (X1) terhadap kemampuan menggiring bola (Y) sebesar 44,89\%.

Korelasi variabel kecepatan (X2) dan kemampuan menggiring bola (Y) sebesar 0,484.Hasil t hitung uji signifikansi variabel kecepatan (X2) dan kemampuan menggiring bola $(\mathrm{Y})$ sebesar 2.82.Dari hasil uji indeks determinasi diketahui pengaruh kecepatan (X) terhadap kemampuan menggiring bola (Y) sebesar 23,43\%.

3. Korelasi variabel motivasi latihan (X3) dan kemampuan menggiring bola (Y) sebesar 0,398.Hasil $t$ hitung uji signifikansi variabel motivasi latihan (X3) dan kemampuan menggiring bola (Y) sebesar 2.212.Dari hasil uji indeks determinasi diketahui pengaruh motivasi latihan (X) terhadap kemampuan menggiring bola (Y) sebesar $15,84 \%$.

4. Korelasi ganda $\left(\mathrm{r}_{\mathrm{X} 1 \times 2 \times 3} \mathrm{y}\right)$ dari tiga variabel bebas (kelincahan, kecepatan dan motivasi latihan) terhadap satu variabel terikat (kemampuan menggiring bola) sebesar 0.517. Hasil t hitung uji signifikansi variabel kelincahan, kecepatan dan motivasi latihan (X1,X2, X3) dan kemampuan menggiring bola (Y) sebesar 3.226.Dari hasil uji indeks 
determinasi diketahui pengaruh kelincahan, kecepatan dan motivasi latihan (X1,X2, X3) terhadap kemampuan menggiring bola $(\mathrm{Y})$ sebesar $28.05 \%$.

\section{KESIMPULAN}

Dari hasil pengolahan data maka dapat ditarik kesimpulan bahwa:

1. Terdapat hubungan positif dan signifikan antara kelincahan terhadap kemampuan menggiring bola.

2. Terdapat hubungan positif dan signifikan antara kecepatan terhadap kemampuan menggiring bola.

3. Terdapat hubungan positif dan signifikan antara motivasi latihan terhadap kemampuan menggiring bola.

4. Terdapat hubungan positif dan signifikan antara kelincahan, kecepatan dan motivasi latihan terhadap kemampuan menggiring bola.

Hasil penelitian ini memberikan implikasi bahwa salah satu upaya untuk meningkatkan kemampuan dribbling dalam permainan futsal adalah dengan meningkatkan kelincahan, kecepatan dan motivasi latihan. Tetapi tetap harus diingat bahwa masih ada faktor lain yang berpengaruh terhadap kemampuan dribbling.

\section{DAFTAR PUSTAKA}

Lhaksana, J. (2011). Mahir Bermain Futsal. Bandung: Mizan.

Sajoto,M.. (1995). Peningkatan dan Pembinaan Kekuatan Kondisi Fisik. Semarang: Dahara Prise.
Arikunto Suharsimi. (1996)Prosedur Penelitian Suatu Pendekatan Praktik. Jakarta : Rineka Cipta.

Ismaryati.(2008).Tes dan Pengukuran Olahraga. Surakarta : LPP UNS dan UPT.Penerbitan dan Pencetakan UNS

Moeloek,Dangsina dan Tjokro,Arjadino. (1984). Kesehatan Olahraga. Jakarta : FK UI

Tudor O. Bompa dan G.Gregory Haff. (2009). 5th Periodization : Theory And Methodology of Training. USA : Human Kinetics

Harsono, (1988).Coaching dan Aspek-aspek Psikologis dalam Coaching. Jakarta: Tambak Kusuma

PASI. (1994).Pengenalan Teori Melatih Atletik (PASI : Program Pendidikan dan sistem Sertifikasi Pelatih Atletik PASI,

Bangso Jens and Magni Mohr. (2003). Fitness Testing In Football (AFC : Taylor\&Francis Ltd. 